\title{
Phospholipase $C$ and protein kinase $C$ involvement in mouse embryonic stem-cell proliferation and apoptosis
}

\author{
L. R. Quinlan, S. Faherty and M. T. Kane* \\ Department of Physiology, National University of Ireland, University Road, Galway, Ireland
}

\begin{abstract}
Activation of the phosphatidylinositol (PtdIns) signal transduction system involves stimulation of phospholipase C (PLC) by hormones and other agonists to produce two second messengers, the inositol phosphate, Ins $(1,4,5) \mathrm{P}_{3}$ which releases calcium from intracellular stores, and diacylglycerol which activates protein kinase C (PKC). This study, using activators or inhibitors of PLC and PKC and a calcium ionophore, examined the role of the PtdIns system in mouse embryonic stem (ES) cells. The PLC inhibitor, U-73122, inhibited ES-cell proliferation and also inhibited PLC activation as evidenced by a decrease in inositol phosphate formation in response to fetal calf serum stimulation. The two PKC activators, the diacylglycerol analogue 1,2, dioctanoyl-sn-glycerol (DOG) and the phorbol ester 12-O-tetra-decanoyl phorbol 13-acetate (TPA),
\end{abstract}

increased cell proliferation in a dose-dependent manner, as did the calcium ionophore, ionomycin. However, costimulation with either ionomycin and DOG or ionomycin and TPA resulted in a reduced number of cells. The PKC inhibitor, bisindolylmaleimide II (Bis II), significantly decreased the number of ES cells, mainly due to increased apoptosis. The possible feedback effect of PKC on PLC was examined by preincubating ES cells with either the PKC inhibitor Bis II or the activator TPA before stimulation of inositol phosphate production with fetal calf serum; preincubation with Bis II increased inositol phosphate formation whereas preincubation with TPA decreased inositol formation. These results indicate that the PtdIns system is involved in the control of ES-cell proliferation and apoptosis.

\section{Introduction}

There is considerable evidence that inositol-containing compounds have an important role in preimplantation embryonic development. Studies in the laboratory of the present authors have shown that inositol is essential for the continued cell proliferation and growth of rabbit blastocysts (Kane, 1988; Kane, 1989; Fahy and Kane, 1992). Inositol has also been shown to stimulate the hatching of hamster blastocysts (Kane and Bavister, 1988). One of the fundamental roles of inositol is that it is part of the phosphatidylinositol (Ptdlns) signal transduction system (reviewed by Berridge, 1992) which involves receptor-stimulated activation of a Ptdlnsspecific phospholipase $\mathrm{C}(\mathrm{PLC})$ resulting in the hydrolysis of phosphatidylinositol $(4,5)$ bisphosphate $\left(\operatorname{Ptd} \operatorname{lns}(4,5) \mathrm{P}_{2}\right)$ to produce the two second messengers inositol $(1,4,5)$ trisphosphate $\left(\operatorname{Ins}(1,4,5) \mathrm{P}_{3}\right)$ which acts to release $\mathrm{Ca}^{2+}$ from internal stores, and diacylglycerol which, together with the released $\mathrm{Ca}^{2+}$, is involved in the activation of protein kinase $\mathrm{C}(\mathrm{PKC})$. It has been shown that mouse (Kane et al., 1992; Higgins and Kane, 2003), rabbit (Fahy and Kane, 1993) and cattle (Hynes et al., 2000) embryos, and mouse embryonic stem (ES) cells

*Correspondence

Email: michael.kane@nuigalway.ie
(Duffy and Kane, 1996) incorporate inositol into the phosphoinositides and inositol phosphates of the Ptdlns signal transduction system. Other workers have shown that inhibitors of PLC inhibit mouse blastocyst formation (Stachecki and Armant, 1996a) and that calcium release in mouse morulae occurs predominantly through the Ins $(1,4,5) \mathrm{P}_{3}$ receptor (Stachecki and Armant, 1996b). The essential role of phosphoinositide compounds in preimplantation development is emphasized by the demonstration that even though exogenous inositol is not necessary for blastocyst formation, knockout of the PLC $\beta 3$ gene prevents development of mouse embryos to the blastocyst stage (Wang et al., 1998).

PKC forms a central control point in many ligandactivated cell-signalling events and is activated by one axis of the Ptdlns signal transduction system through diacylglycerol. PKC represents a family of at least 12 serine/threonine kinases that are involved in a myriad of signal transduction events in response to specific hormonal and growth factor stimuli (reviewed by Nishizuka, 1992). One specific aspect of PKC that is relevant to the present study is that PKC has been shown to play a vital role in regulating early events in embryonic development (reviewed by Gallicano et al., 1997a). This role is at least partly linked to its role in regulation of cell-cycle control in both yeast and mammalian cells (reviewed by Livneh and Fishman, 1997). PKC is also 
thought to play an important role in oocyte remodelling at zygote formation in many species (Gallicano et al., 1997b).

The present study used mouse ES cells as a model for embryonic growth. ES cells are a stable cell line, which are derived from the inner cell mass of preimplantation embryos. These cells closely resemble their in vivo counterparts and thus provide a stable in vitro model of embryo growth and development and provide a means whereby specific signalling systems can be investigated. In the data presented here, using activators or inhibitors of PLC and PKC and a calcium ionophore, the possible roles of the Ptdlns signalling system and PKC in ES-cell proliferation and apoptosis were examined.

\section{Materials and Methods}

\section{ES-cell culture}

Mouse ES cells of the CCE cell line were cultured in the standard culture medium for ES cells (Robertson, 1987), Dulbecco's modified Eagles medium (DMEM; Gibco BRL, Life Technologies Ltd, Paisley) supplemented with penicillin $\mathrm{G}\left(150 \mathrm{U} \mathrm{ml}^{-1}\right)$, streptomycin sulphate $\left(150 \mu \mathrm{g} \mathrm{ml}^{-1}\right), \beta$-mercaptoethanol $\left(0.007 \mu \mathrm{g} \mathrm{ml}^{-1}\right)$, mouse leukaemia inhibitory factor (LIF; $1000 \mathrm{U} \mathrm{ml}^{-1}$, ESGRO $^{\text {TM }}$, Gibco BRL) (Williams et al., 1988) and 5\% fetal calf serum (FCS). Cells were grown on gelatinized tissue culture flasks and 24-well plates in an incubator maintained at $37^{\circ} \mathrm{C}$ in an atmosphere of $5 \% \mathrm{CO}_{2}$ in air.

\section{Cell proliferation studies}

For all studies except apoptosis, ES cells were first grown to $60 \%$ confluency in $25 \mathrm{~cm}^{2}$ flasks, and then the exponentially growing cells were trypsinized and seeded at $2 \times 10^{5}$ cells ml ${ }^{-1}$ in 24 -well plates in fresh standard DMEM and allowed to attach for $24 \mathrm{~h}$.

For inhibitor studies, after the attachment period, the inhibitor being investigated was added for 24 or $48 \mathrm{~h}$ and culture was carried out in standard DMEM plus $10 \%$ FCS. For activator studies, the cells were further cultured in standard medium without FCS after the attachment period, supplemented with $0.1 \%(\mathrm{w} / \mathrm{v})$ essentially fattyacid free BSA (Sigma-Aldrich, Poole; cell-culture grade) for $24 \mathrm{~h}$ in the presence of various concentrations of PKC activators or the calcium ionophore, ionomycin.

When it was necessary to dissolve inhibitors or activators in non-aqueous solvents (ethanol, DMSO), controls were treated with diluent at the same concentration as the highest concentration of inhibitor or activator being examined.

Cell viability was determined by dye exclusion in which cells were stained with ethidium bromide and acridine orange. In studies of cell viability and apoptosis, cells $\left(10 \times 10^{4} \mathrm{ml}^{-1}\right)$ were grown on Eppen- dorf CELLocate ${ }^{\circledR}$ microgrid coverslips (Eppendorf AG, Hamburg).

\section{Cell proliferation assays}

The effects of various PLC and PKC activators and inhibitors on cell proliferation were assayed by the MTT (3-[4,5-dimethylthiazol-2-yl]-2,5, diphenyltetrazolium bromide) assay (Mosmann, 1983; Denizot and Laing, 1986) at the end of a 24 or $48 \mathrm{~h}$ treatment period. The MTT salt (Sigma cat no. M2128) was prepared as a $5 \mathrm{mg} \mathrm{m}^{-1}$ stock solution in PBS and used at a working concentration of $1 \mathrm{mg} \mathrm{ml}^{-1}$ in DMEM culture medium without phenol red. At the end of the cell-culture treatment period, the cells were incubated in MTT solution for $3 \mathrm{~h}$ at $37^{\circ} \mathrm{C}$. The solution was removed and the blue formazan product was dissolved with 2propanol. The absorbance was then read at $550 \mathrm{~nm}$ with $690 \mathrm{~nm}$ reference. In certain cases cell proliferation was also measured by direct cell counting using a haemocytometer.

\section{Apoptosis assay}

The effects of various activators and inhibitors of PLC and PKC on cell viability and apoptosis were measured. The cells were fixed with $2 \%(\mathrm{w} / \mathrm{v})$ paraformaldehyde and stored under PBS for analysis at the end of the cellculture treatment period. Cells were stained with either ethidium bromide or acridine orange to measure viability or with the TUNEL in situ cell death detection kit from Roche Molecular Biochemicals (Roche Diagnostics Ltd, Lewes) to measure apoptosis. TUNEL-stained cells were counterstained with propidium iodide and apoptotic nuclei were counted using confocal microscopy.

\section{Inositol phosphate assay}

Unless otherwise stated, the general strategy to assess the effects of various activators and inhibitors of PLC and PKC on Ptdlns-specific PLC formation of inositol phosphates in ES cells was as follows. After the $24 \mathrm{~h}$ attachment period, $2.5 \mu \mathrm{Ci}\left[2-{ }^{3} \mathrm{H}\right]$ inositol $\mathrm{ml}^{-1}$ was added for a further $24 \mathrm{~h}$ in FCS-free inositol-free DMEM. Treatment with activators or inhibitors was carried out during the labelling period; timing of treatments is outlined below under specific experiments. In all cases, lithium chloride $\left(10 \mathrm{~mol} \mathrm{I}^{-1}\right.$ final concentration) was added 25 min before the end of the labelling period to facilitate detection of labelled inositol phosphates by preventing their breakdown to free inositol (Berridge et al., 1982). After a further $10 \mathrm{~min}$ the Ptdlns system was stimulated by the addition of $10 \%$ FCS. At the end of the $24 \mathrm{~h}$ labelling period ( $15 \mathrm{~min}$ later), the reaction was stopped with $5 \%(\mathrm{w} / \mathrm{v})$ perchloric acid and the radiolabelled inositol phosphates extracted as described by Duffy et al. (1998). Extracted inositol phosphates were 


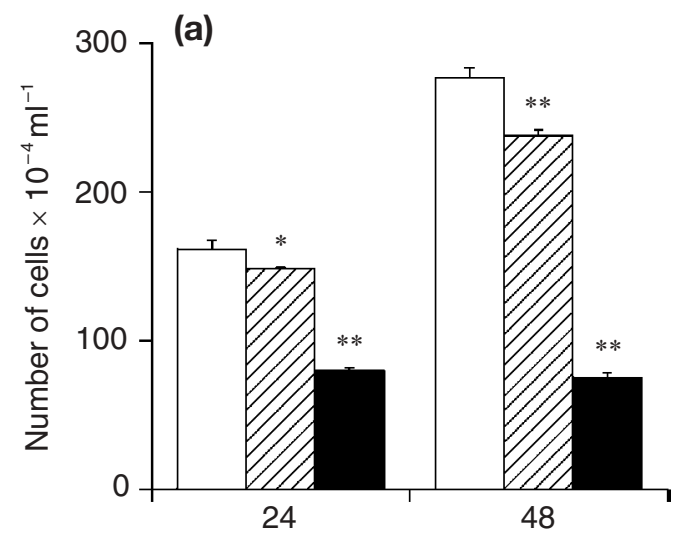

Duration of incubation with $U-73122(h)$
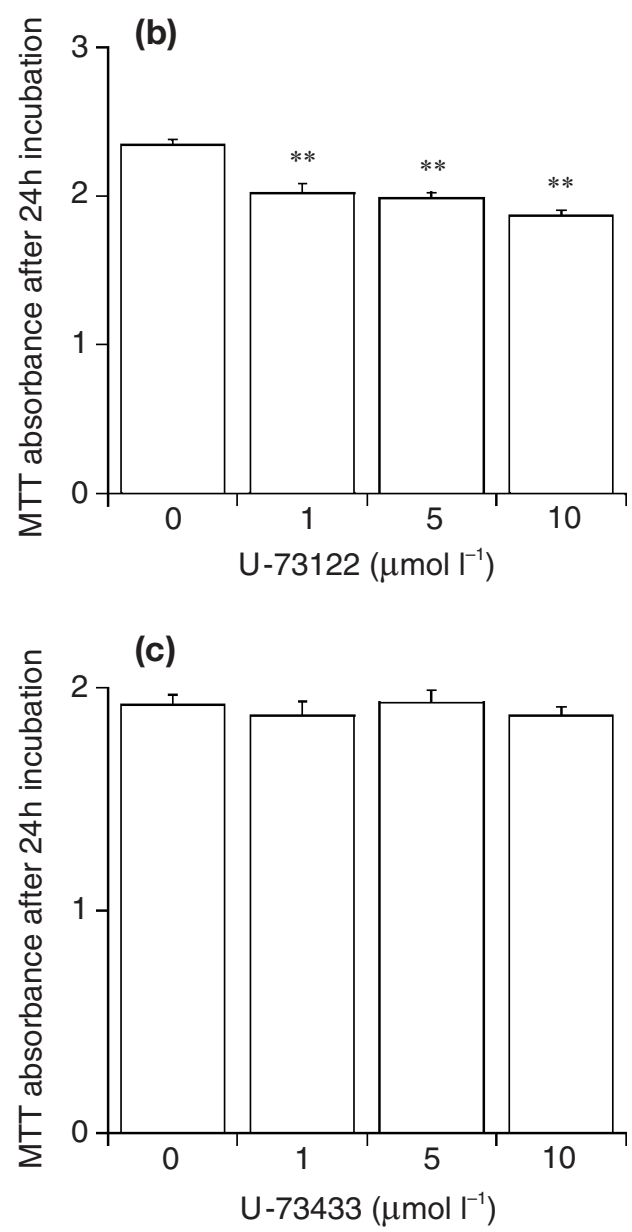

Fig. 1. The effects of the phospholipase $C$ inhibitor U-73122 and its inert analogue, $\mathrm{U}-73433$, on the number of mouse embryonic stem (ES) cells in culture. (a) Effect of U-73122 (0: $\square$; 1: V/:; and $\left.10 \mu \mathrm{mol} \mathrm{I}^{-1}: \mathbf{\square}\right)$ for 24 and $48 \mathrm{~h}$ on the number of ES cells as determined by haemocytometric counting. Values are means \pm SEM for eight replicates. (b) Effect of U-73122 on ES cells over $24 \mathrm{~h}$, as measured by the 3-[4,5-dimethylthiazol-2-yl]-2,5, diphenyltetrazolium bromide (MTT) cell-proliferation assay. Absorbance values at 550 $\lambda-690 \lambda$ are means \pm SEM for eight replicates. (c) Effect of U-73433 for $24 \mathrm{~h}$ on ES cells as measured by the MTT proliferation assay. Absorbance values at $550 \lambda-690 \lambda$ are means \pm separated by standard methods using Dowex anion exchange chromatography (Berridge et al., 1983; Duffy et al., 1998) and their incorporation into the inositol monophosphate $\left(\operatorname{InsP}_{1}\right)$ and the $>\operatorname{Ins} P_{1}$ fractions was quantified by liquid scintillation counting. $\left[{ }^{3} \mathrm{H}\right]$ inositol was obtained from Amersham International plc (Amersham), and NEN, Dupont de Nemours (Bad Homburg).

\section{Statistical analysis}

All experiments were analysed by ANOVA followed in some experiments by a comparison of treatment means with the control using the Bonnferroni-Dunn test.

\section{Results}

Experiment 1: effect of the PLC inhibitor U-73122 on number of ES cells, the induction of apoptosis and inositol phosphate formation

The effects on the number of cells of $24 \mathrm{~h}$ incubation with U-73122 and its inert analogue, U-73433 (1, 5 and $10 \mu \mathrm{mol} \mathrm{I}^{-1}$ ), were measured by the MTT assay; effects of 24 and $48 \mathrm{~h}$ incubation with $\mathrm{U}-73122$ ( 1 and $10 \mu \mathrm{mol} \mathrm{I}{ }^{-1}$ ) were also measured by haemocytometric cell counting. There was a significant effect $(P<0.001)$ of the PLC inhibitor U-73122 and duration of incubation with U-73122 on ES-cell proliferation (Fig. 1a,b). U-73122 reduced the number of ES cells over 24 and $48 \mathrm{~h}$ as measured by haemocytometric cell counting (Fig. 1a) and as determined by the MTT assay when measured over $24 \mathrm{~h}$ (Fig. 1b). The inert analogue U73433 had no effect on the number of cells $(P>0.05)$ over the same concentration range (Fig. 1c).

The effects of $24 \mathrm{~h}$ incubation with $\mathrm{U}-73122(0.5$, 1,5 and $10 \mu \mathrm{mol} \mathrm{I}^{-1}$ ) on apoptosis and cell viability were examined. Viability assays showed that $\geqslant 98 \%$ cells were viable at the end of the treatment period and that U-73122 had no effect on apoptosis (Fig. 2). The increases in apoptosis observed over the various time periods were acceptable for cell lines in culture (Han et al., 2000), reaching a maximum of approximately $6 \%$ at $24 \mathrm{~h}$. The failure of U-73122 to increase the incidence of dead or apoptotic cells coupled with its effect in reducing the number of cells relative to the control after 24 and $48 \mathrm{~h}$ incubation indicates that U-73122 reduced the number of cells in culture by inhibiting ES-cell proliferation.

The effects at the same concentrations of U-73122 and U-73433 on radiolabelled inositol phosphate formation in the presence and absence of FCS were determined. U-73122 significantly $(P<0.001)$ inhibited both FCSstimulated (Fig. 3a) and basal unstimulated (Fig. 3b)

SEM for eight replicates. ${ }^{*} P<0.05,{ }^{* *} P<0.001$, significantly different from value for no addition of inhibitor at same time point. 


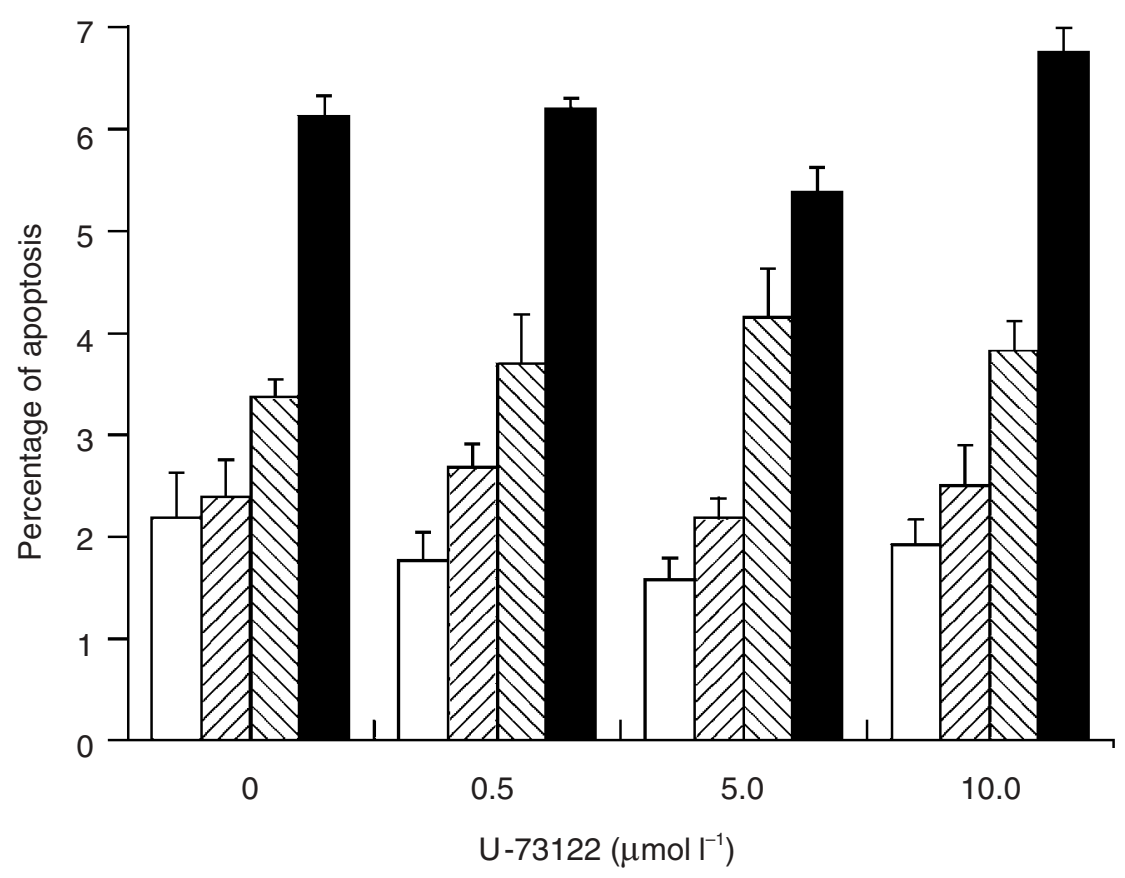

Fig. 2. Effect of concentration of the phospholipase $C$ inhibitor U-73122 and duration of incubation (4: $\square ; 8:$ V/; 12 : 压; and $24 \mathrm{~h}$ : $\mathbf{0})$ on apoptosis in mouse embryonic stem cells. Values are means \pm SEM for six replicates.

inositol phosphate formation in a dose-dependent manner. The highest concentration $\left(10 \mu \mathrm{mol} \mathrm{I}^{-1}\right)$ caused a decrease of approximately $58 \%$ in FCS-stimulated inositol phosphate formation and $22 \%$ in unstimulated formation. The inert analogue U-73433 had no effect on inositol phosphate formation (results not shown). On the basis of the ability of U-73122 to inhibit PLC activity, these results provide evidence that PLC has a controlling role in ES-cell proliferation.

Experiment 2: effects of PKC activators, DOG and TPA, on ES-cell proliferation

The effects on ES-cell proliferation of incubation for $24 \mathrm{~h}$ with the diacylglycerol analogue, 1,2, dioctanoylsn-glycerol (DOG), at concentrations of 10, 100 and $1000 \mathrm{nmol} \mathrm{I}^{-1}$ and the phorbol ester 12 -O-tetra-decanoyl phorbol 13-acetate (TPA) at concentrations of 1, 10 and $50 \mathrm{nmol} \mathrm{I-1}$ were measured by the MTT assay. The effects of stimulation with DOG were compared with stimulation with $10 \%$ FCS.

Incubation with DOG had a significant $(P<0.001)$ effect on ES-cell proliferation (Fig. 4a). DOG (10 nmol $\mathrm{I}^{-1}$ ) increased cell proliferation by approximately $15 \%$ whereas $100 \mathrm{nmol}$ DOG I-1 increased cell proliferation by approximately $40 \%$. The highest concentration used, $1000 \mathrm{nmol} \mathrm{I}^{-1}$, had no effect on cell proliferation. However, FCS had a much greater stimulatory effect on ES-cell proliferation than the optimal concentration of
DOG $(P<0.001)$; FCS increased cell proliferation 2.7fold as compared with the 0 control.

TPA had a significant $(P<0.001)$ effect on ES-cell proliferation (Fig. 4b). TPA $\left(1 \mathrm{nmol} \mathrm{I}^{-1}\right)$ increased cell proliferation by approximately $35 \%$, whereas higher concentrations reduced the number of cells. TPA $(50 \mathrm{nmol}$ $\mathrm{I}^{-1}$ ) reduced the number of cells by approximately $23 \%$. These results support the idea that PKC is involved in the control of ES-cell proliferation.

Experiment 3: effect of the calcium ionophore alone and in combination with DOG or TPA on ES-cell proliferation

The effect of incubation for $24 \mathrm{~h}$ with the calcium ionophore, ionomycin $\left(0.1,1\right.$ and $\left.10 \mu \mathrm{mol} \mathrm{I}^{-1}\right)$ on EScell proliferation was measured by the MTT assay.

Co-stimulation studies involving dual treatment with ionomycin $\left(0.1\right.$ and $\left.1 \mu \mathrm{mol} \mathrm{I} \mathrm{I}^{-1}\right)$ and DOG and TPA over the concentration range used in Expt 2 were also performed and cell proliferation was again measured by the MTT assay. Ionomycin had a significant effect $(P<0.001)$ on ES-cell proliferation (Fig. 5a). Ionomycin $\left.(0.1 \mu \mathrm{mol} \mathrm{I})^{-1}\right)$ increased cell proliferation by approximately $67 \%$, whereas $1 \mu \mathrm{mol}$ ionomycin $\mathrm{I}^{-1}$ increased cell proliferation by approximately $96 \%$. However, the number of cells in $10 \mu \mathrm{mol}$ ionomycin $\mathrm{I}^{-1}$ was decreased markedly, relative to the $1 \mu \mathrm{mol} \mathrm{I}^{-1}$ concentration, indicating that higher concentrations were less active in 

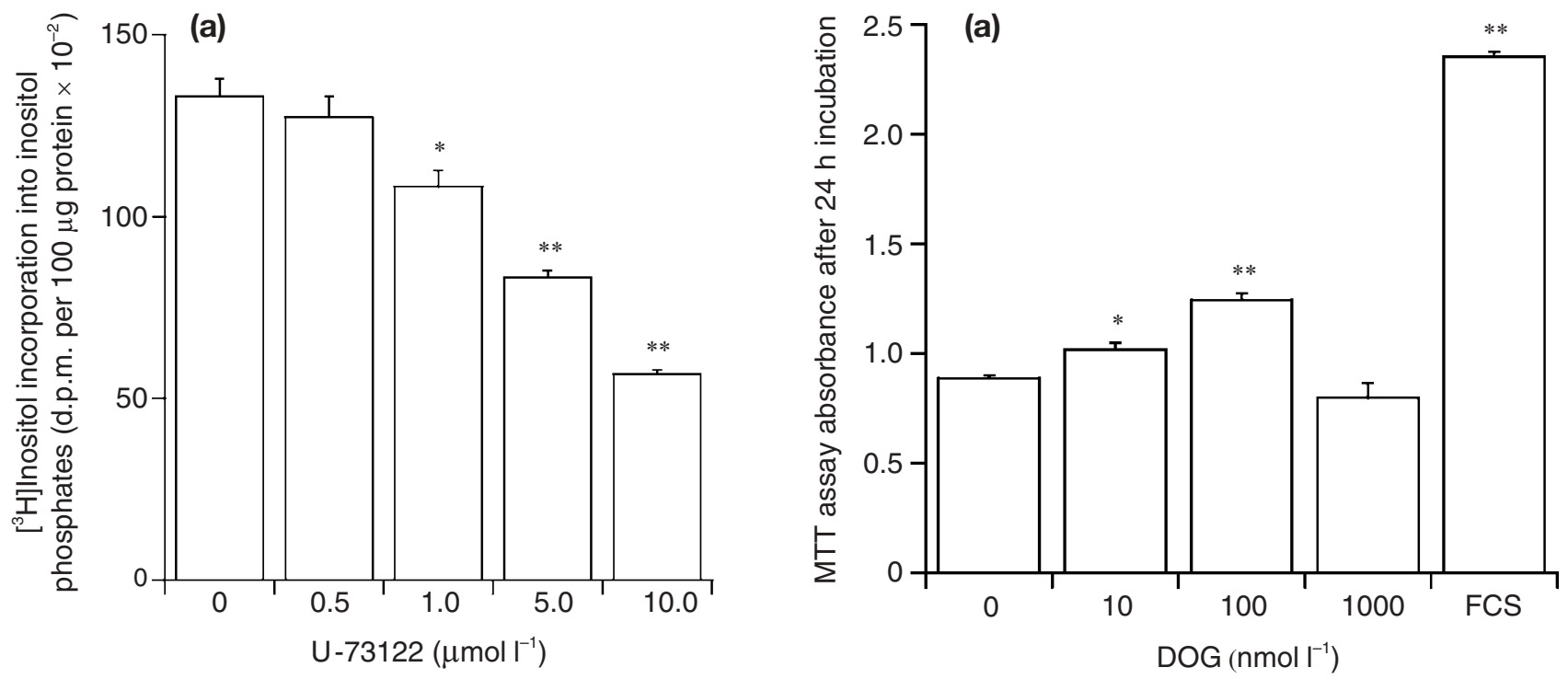

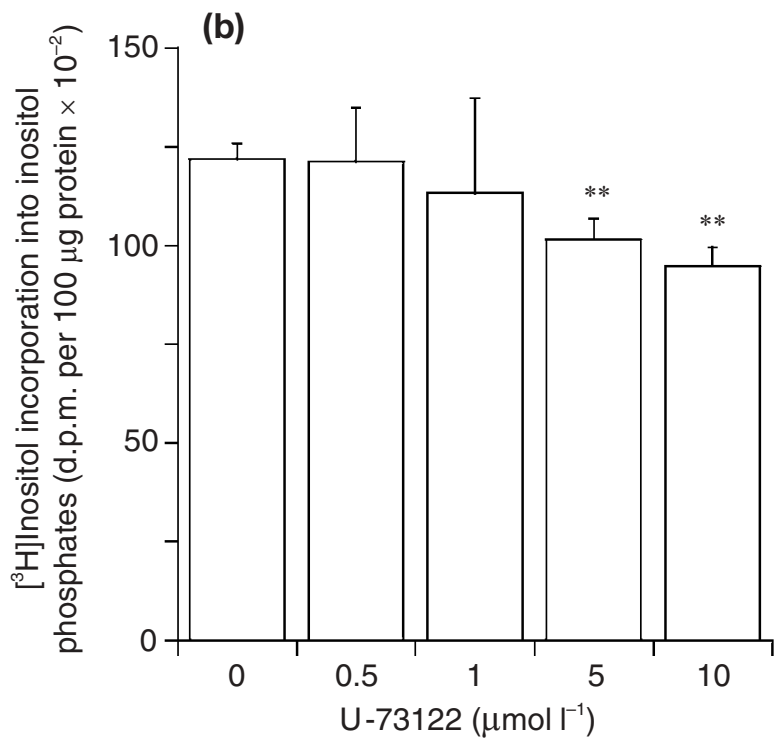

Fig. 3. Effect of the phospholipase C inhibitor U-73122 on (a) fetal calf serum-stimulated and (b) basal unstimulated inositol phosphate formation. Values are means \pm SEM for eight replicates. ${ }^{*} P<0.05$, ${ }^{* *} P<0.001$, significantly different from value for no addition of inhibitor.

stimulating cell proliferation or else caused some cell death.

There was no significant effect of either ionomycin or DOG in the ionomycin-DOG co-stimulation experiment or of ionomycin-TPA in the ionomcyin-TPA experiment. However, there was a significant interaction $(P<0.001)$ between ionomycin and DOG (Fig. 5b) and between ionomycin and TPA (Fig. 5c). These significant negative interactions were due to the fact that the responses to DOG and TPA were decreased by increasing concentrations of ionomycin. Whereas both DOG and

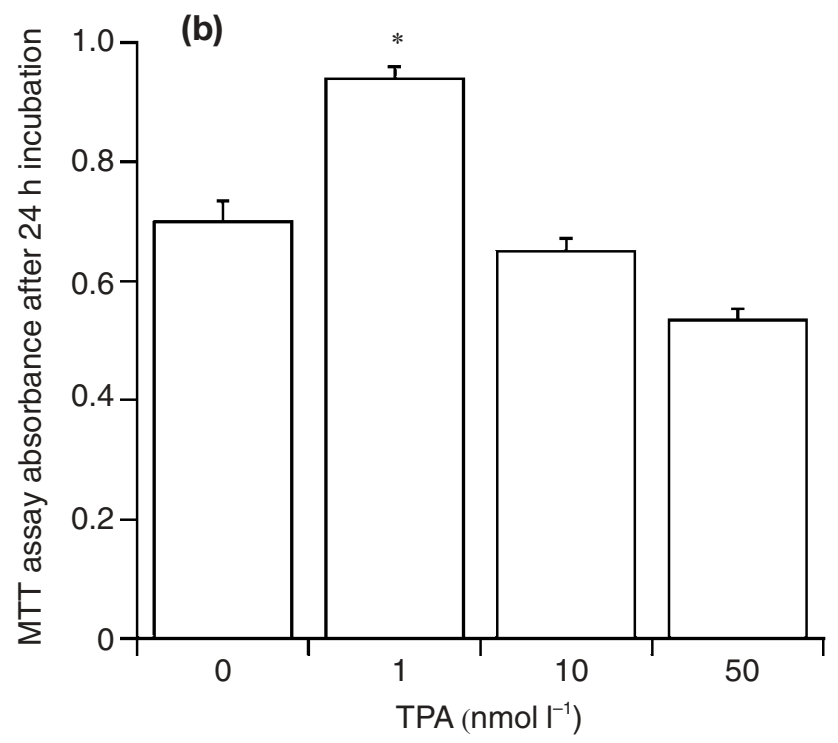

Fig. 4. Effect of protein kinase $C$ activators on mouse embryonic stem-cell proliferation as determined by the 3-[4,5-dimethylthiazol-2-yl]-2,5, diphenyl-tetrazolium bromide (MTT) cellproliferation assay. (a) Effect of the diacylglycerol analogue 1,2, dioctanoyl-sn-glycerol (DOG) and fetal calf serum. (b) Effect of the phorbol ester, 12-O-tetra-decanoyl phorbol 13-acetate (TPA). Absorbance values are means \pm SEM for eight replicates for both activators. ${ }^{*} P<0.01,{ }^{* *} P<0.001$, significantly different from value for no addition of activator.

TPA were stimulatory in the absence of ionomycin, only the lowest concentration of DOG $\left(10 \mathrm{nmol} \mathrm{I}^{-1}\right)$ in the presence of $0.1 \mu \mathrm{mol}$ ionomycin $\mathrm{I}^{-1}$ resulted in a slight increase in cell proliferation (Fig. 5b). All other concentrations of DOG and all concentrations of TPA (Fig. 5c) tested in the presence of either concentration of ionomycin reduced the number of cells. 

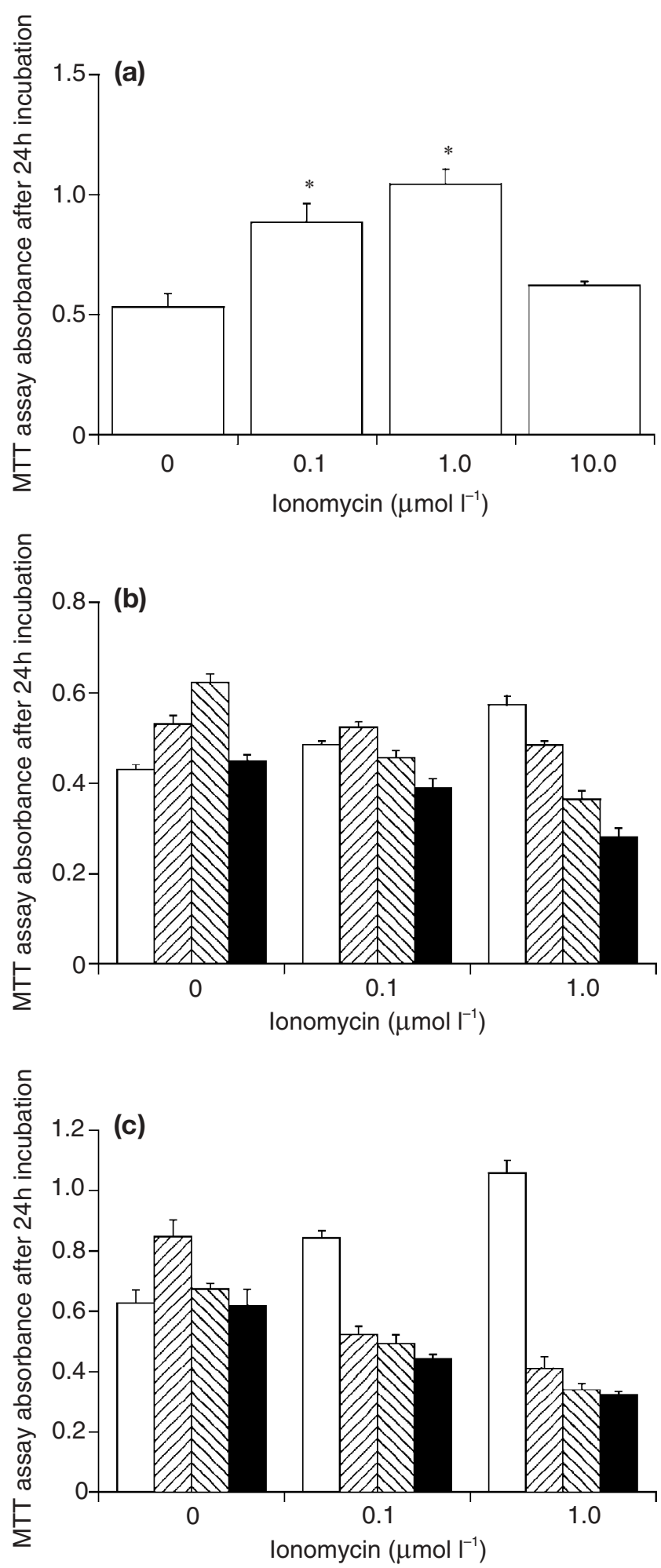

Fig. 5. Effects of the calcium ionophore, ionomycin, both alone and in combination with the protein kinase $\mathrm{C}$ activators 1,2, dioctanoyl-sn-glycerol (DOG) or 12-O-tetra-decanoyl phorbol 13acetate (TPA) on mouse embryonic stem (ES)-cell proliferation as measured by the 3-[4,5-dimethylthiazol-2-yl]-2,5, diphenyltetrazolium bromide (MTT) cell-proliferation assay. (a) Effect of ionomycin on cell proliferation. Absorbance values are means \pm SEM
These results provide evidence that calcium may have a key role in ES-cell proliferation.

Experiment 4: effects of the PKC inhibitor bisindolylmaleimide II on number of ES cells and incidence of apoptosis

The effect of $24 \mathrm{~h}$ incubation with bisindolylmaleimide II (Bis II) at 0.5, 5 and $10 \mu \mathrm{mol} \mathrm{I}^{-1}$ or its inert analogue Bis $V$ at $0.5,5,10$ and $20 \mu \mathrm{mol} \mathrm{I}{ }^{-1}$ on the number of cells was examined by MTT assay. The effects on cell viability and extent of apoptosis of incubation with Bis II $(0.5,5$ and $10 \mu \mathrm{mol} \mathrm{I}^{-1}$ ) for $24 \mathrm{~h}$ were also determined.

Bis II at concentrations $\geqslant 5 \mu \mathrm{mol} \mathrm{I}{ }^{-1}$ significantly $(P<$ 0.001) depressed the number of ES cells in a dosedependent manner as assessed by the MTT assay (Fig. 6a); $10 \mu \mathrm{mol}$ Bis $\mathrm{II} \mathrm{I}^{-1}$ caused a $26 \%$ decrease in the number of ES cells over $24 \mathrm{~h}$. The inactive analogue Bis $V$ had no effect on the number of ES cells over the same period (Fig. 6b). Viability assays showed $\geqslant 98 \%$ cells to be viable.

There was a significant effect $(P<0.001)$ of Bis II and duration of incubation on apoptosis of ES cells; the highest concentration of Bis II $\left(10 \mathrm{mmol} \mathrm{I}^{-1}\right)$ increased the percentage of apoptosis approximately fivefold (Fig. 7). Thus, the effect of Bis II in reducing the number of ES cells in culture may not be due to an anti-proliferative effect but to its effect in increasing apoptosis.

\section{Experiment 5: effect of PKC activation or inhibition on inositol phosphate formation}

The effect of acute inhibition or activation of PKC, before FCS treatment, on FCS stimulation of inositol phosphate formation was examined. Cells were preincubated with PKC inhibitor Bis II $(0.5,5$ and $10 \mu \mathrm{mol}$ $\mathrm{I}^{-1}$ ) or its inert analogue Bis $\mathrm{V}$ for 30 min before the end of the $24 \mathrm{~h}$ labelling period for the study of acute PKC inhibition. Cells were pre-incubated with PKC activator TPA (100 nmol I-1) either 1 or $2 \mathrm{~h}$ before the end of the $24 \mathrm{~h}$ labelling period for the study of acute PKC activation.

Preincubation with Bis II caused a dose-dependent increase $(P<0.001)$ in FCS-stimulated inositol phosphate formation (Fig. 8a). Bis II $\left(10 \mu \mathrm{mol} \mathrm{I} \mathrm{I}^{-1}\right)$ caused an increase of approximately $26 \%$ in inositol phosphate formation. The inactive analogue Bis $V$ had no effect on inositol phosphate formation (Fig. 8b). Preincubation with TPA (100 nmol I-1) before FCS stimulation caused

for eight replicates. (b) Effect of co-incubation with DOG (0: $\square$;

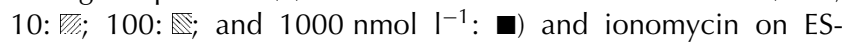
cell proliferation. Absorbance values are means \pm SEM for four replicates. (c) Effect of co-incubation with TPA (0: $\square$; 1: W/ 10: and $\left.50 \mathrm{nmol} \mathrm{I}^{-1}: \mathbf{a}\right)$ and ionomycin on ES-cell proliferation. Absorbance values are means \pm SEM for four replicates. ${ }^{*} P<0.001$ significantly different from value for no addition of activator. 


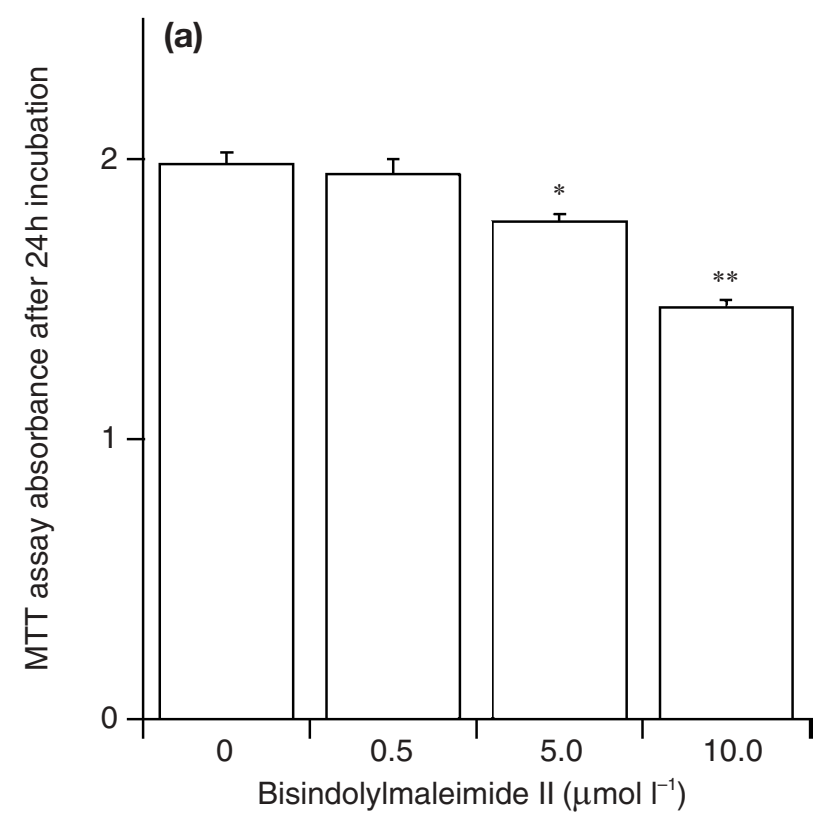

(b)

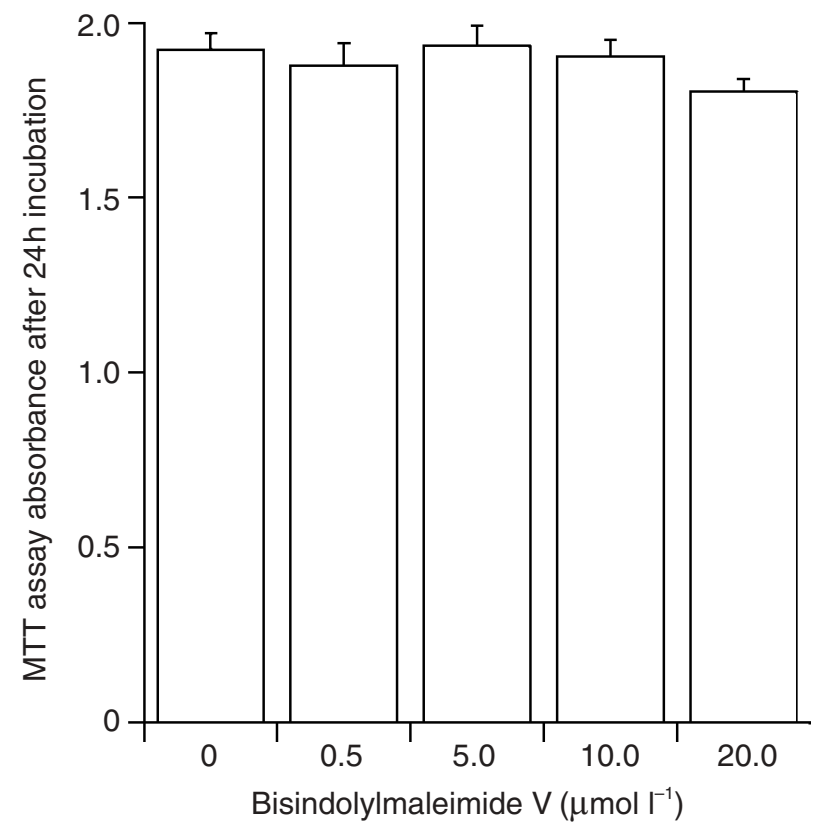

Fig. 6. Effect of bisindolylmaleimides (Bis II and Bis V) on mouse embryonic stem cells as measured by the 3-[4,5-dimethylthiazol2-yl]-2,5, diphenyl-tetrazolium bromide (MTT) cell-proliferation assay. (a) Effects of the protein kinase C inhibitor, Bis II. (b) Effect of the inert analogue Bis $\mathrm{V}$. Values for absorbance are means \pm SEM for eight replicates for both (a) and (b). ${ }^{*} P<0.01,{ }^{* *} P<0.001$, significantly different from value for no addition of inhibitor.

a decrease $(P<0.001)$ in inositol phosphate formation (Fig. 8c). Preincubation with TPA for 1 and $2 \mathrm{~h}$ caused an approximate $26 \%$ and $35 \%$ decrease in inositol phosphate production, respectively.

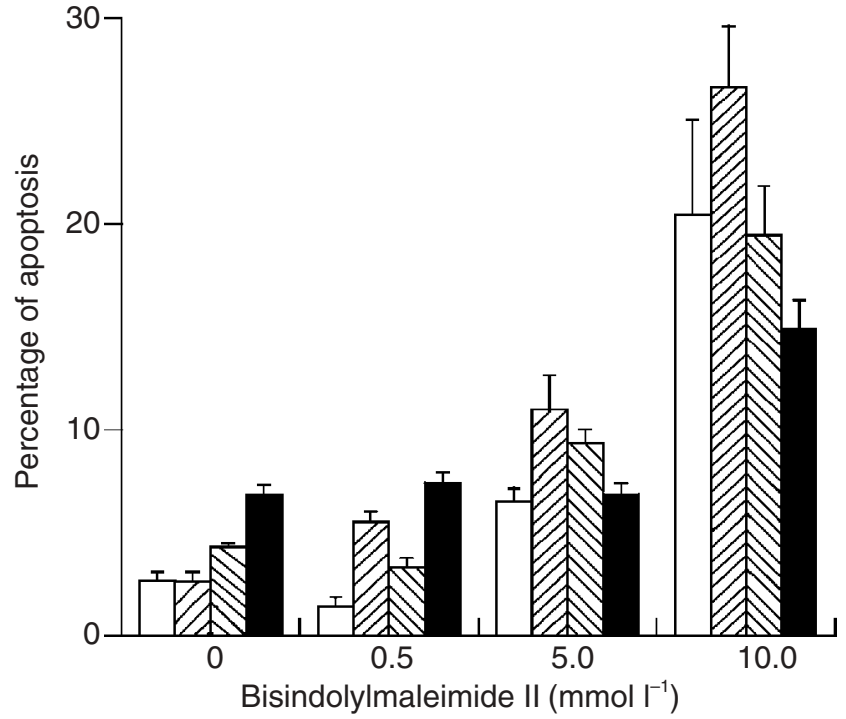

Fig. 7. Effect of concentration of the protein kinase $\mathrm{C}$ inhibitor bisindolylmaleimide II and duration of incubation (4: $\square$; 8: 戊; 12: 巡; and $24 \mathrm{~h}: \mathbf{\square})$ on apoptosis in mouse embryonic stem cells. Values are means \pm SEM for six replicates over three blocks.

These results clearly demonstrate that the Ptdlns system is active and tightly regulated via PKC activity in ES cells; increased PKC activity tended to downregulate and decreased PKC activity to upregulate the PtdIns system.

\section{Discussion}

Previous work in this laboratory (Duffy and Kane, 1996) has demonstrated that components of the PtdIns signal transduction system are present in ES cells. Demonstrating the presence of Ptdlns signal components in ES cells does not, however, prove that the system is essential for ES-cell proliferation. In examining the role of the Ptdlns system in ES-cell proliferation in the present work, activators or inhibitors of PLC and PKC and a calcium ionophore were used to investigate the importance of PLC, PKC and intracellular calcium in EScell proliferation.

Studies of the role of PLC in cell function are hindered by the absence of a suitable specific cell permeable activator of PLC. In the absence of such an activator, the specific PLC inhibitor, U-73122 (Powis and Phil, 1994; Wang et al., 1994) was used in the present study. The fact that U-73122 significantly reduced the number of ES cells in a dose-dependent manner $\left(\leqslant 1 \mu \mathrm{mol} \mathrm{I}^{-1}\right)$ but did not decrease cell viability or increase the incidence of apoptotic cells, shows that the effect of U-73122 involved a specific inhibition of ES-cell proliferation and not a general cytotoxic or apoptotic effect. Over $24 \mathrm{~h}$, cell proliferation was inhibited and over $48 \mathrm{~h}$ it was abolished by U-73122. U-73122 too had a similar dose-dependent 


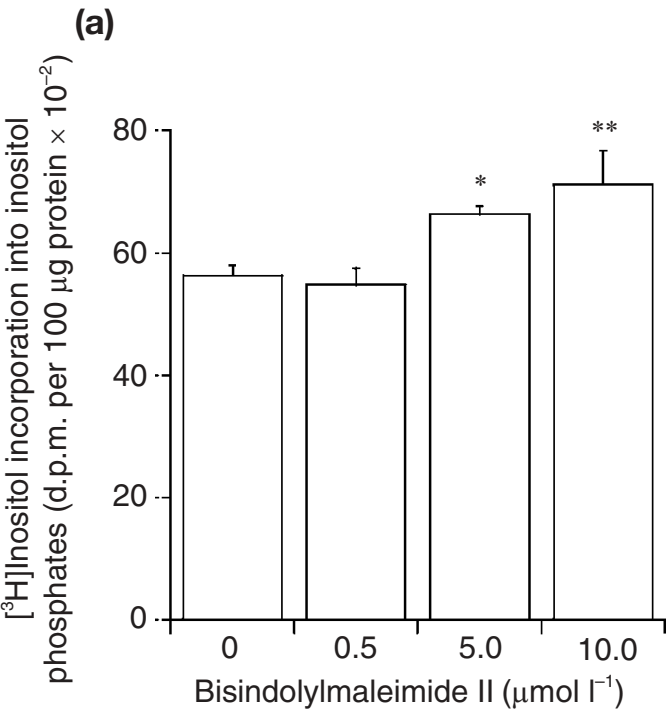

(b)

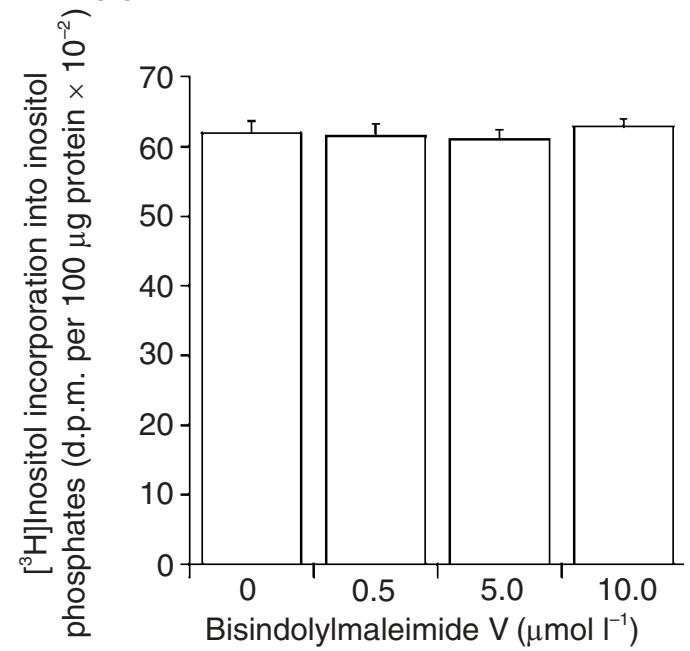

(c)

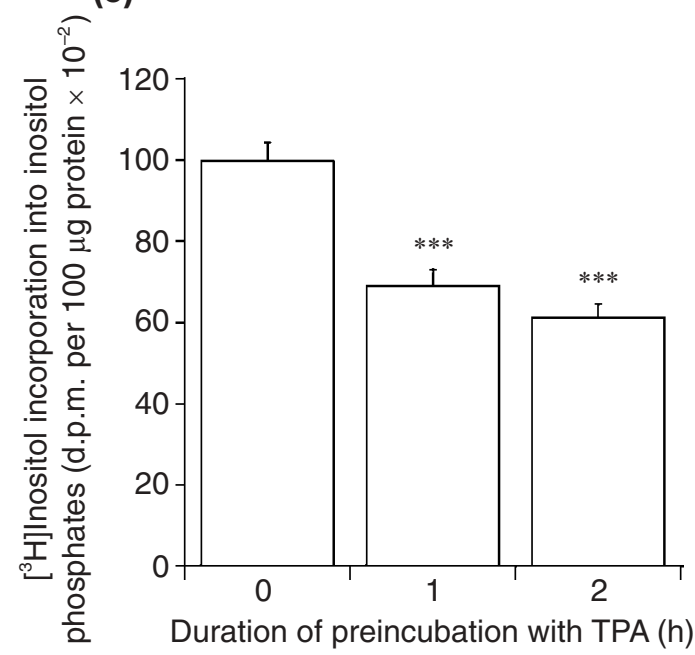

Fig. 8. The effect of acute inhibition or activation of protein kinase C (PKC) on fetal calf serum-stimulated inositol phosphate formation. Effect of preincubation (a) with the PKC inhibitor, bisindolylmaleimide II (30 min); (b) preincubation with the inert inhibitory effect on the formation of inositol phosphates stimulated by FCS. Evidence for the specificity of U-73122 action on PLC was provided by the fact that the very similar but inert analogue U-73343 (Bleasdale et al., 1990; Powis and Phil, 1994) had no effect on either ES-cell proliferation or inositol phosphate formation. These results indicate that PLC has a controlling role in ES-cell proliferation. As ES cells are derived from the inner cell mass of the blastocyst, this work on the effect of PLC inhibition in ES cells is in agreement with the work of Stachecki and Armant (1996a) showing that the regulation of blastocyst formation in mice is mediated through a PLC-dependent pathway that can be inhibited by U-73122.

In ES cells U-73122 inhibited basal concentrations of inositol phosphate formation (that is, in the absence of FCS stimulation). This finding indicates the presence of an as yet unknown autocrine or paracrine factor produced by the ES cells themselves that stimulates phosphoinositide turnover, causing the system to be constitutively active in ES cells.

The two second messengers produced by activation of PLC action, diacylglycerol and Ins $(1,4,5) \mathrm{P}_{3}$, stimulate PKC and increase intracellular calcium (Berridge, 1992); the PKC activators, DOG and TPA, and a calcium ionophore, ionomycin, were used to mimic these actions on ES cells (Berry and Nishizuka, 1990).

The results with DOG and TPA support the hypothesis that PKC is involved in the control of ES-cell proliferation. DOG at concentrations of 10 and $100 \mathrm{nmol} \mathrm{I}^{-1}$ and TPA

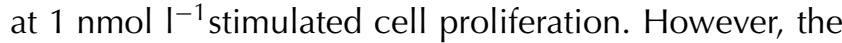
results also showed that super-activation of PKC led to growth arrest, as $1000 \mathrm{nmol}$ DOG $\mathrm{I}^{-1}$ was slightly growth-inhibitory and TPA was inhibitory at 10 and $50 \mathrm{nmol} \mathrm{I}{ }^{-1}$; this effect is presumably through PKC downregulation (Kraft and Anderson, 1983; Kishimoto et al., 1989).

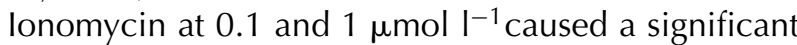
increase in cell proliferation, which was abolished at $10 \mu \mathrm{mol} \mathrm{I}{ }^{-1}$ as its effect tended to become growthinhibitory or cytotoxic. Treatment with ionomycin causes a rapid and sustained increase in intracellular calcium (Hanson and Ziegler, 2001) without the requirement for an external stimulus to open specific calcium channels. Thus, the ionomycin treatment bypasses the role of Ins $(1,4,5) \mathrm{P}_{3}$ in releasing calcium from internal stores. The majority of effects elicited by calcium are via interaction with the calcium-binding protein calmodulin (Billingsley et al., 1990). Whatever the mechanism involved in the present study, the results indicate that calcium is a key messenger in ES-cell proliferation.

analogue bisindolylmaleimide $\mathrm{V}$ (30 $\mathrm{min})$; and (c) preincubation with the PKC activator 12-O-tetra-decanoyl phorbol 13-acetate (TPA; 1 or $2 \mathrm{~h}$ ). In all cases, values are means \pm SEM for eight replicates. ${ }^{*} P<0.05,{ }^{*} P<0.01,{ }^{* * *} P<0.001$, significantly different from value for no addition of inhibitor or activator. 
Co-stimulatory studies were also performed, involving dual treatment with ionomycin and DOG or TPA. Only $10 \mathrm{nmol} \mathrm{DOG} \mathrm{I}^{-1}$ in the presence of $0.1 \mu \mathrm{mol}$ ionomycin $I^{-1}$ resulted in a slight increase in cell proliferation. All other concentrations of DOG and all concentrations of TPA tested in the presence of either concentration of ionomycin proved to be growth-inhibitory or toxic. Co-incubation with ionomycin in effect reduced the concentrations of both activators required to produce a growth-inhibitory response. As PKC is a known target for both DOG and TPA and calcium is necessary for the activation of PKC (Takai et al., 1979; Quest, 1996), one explanation for these results is that there is a fine balance between intracellular calcium concentrations and the concentration of DOG or TPA required to activate or downregulate PKC. However, other effects of calcium, not related to PKC, may also be involved.

Whereas the results with PKC activators provided strong evidence for a role for PKC in controlling EScell proliferation, the results with the PKC inhibitor Bis II alone are more complex. Although Bis II reduced the number of ES cells as measured by the MTT assay in a dose-dependent manner, it also increased the incidence of apoptosis; the highest concentration of Bis II $(10 \mu \mathrm{mol}$ $\mathrm{I}^{-1}$ ) induced significant (16\%) apoptosis and this increase in apopototic cells is sufficient to account for much if not all the decrease in the number of cells measured by the MTT assay. The inert analogue Bis $V$ had no effect in the MTT assay. The MTT assay measures cell metabolic activity including mitochondrial activity (Denizot and Laing, 1986; Pechhold and Kabelitz, 1998) and thus can reflect not just changes in cell proliferation but also decreases in cell activity or cell death due to cell apoptosis or necrosis. There was no effect of Bis II on cell death as measured by live-dead staining in the present study. This result is not unusual; Savickiene et al. (1999) found that the PKC inhibitor calphostin C caused considerable apoptosis ( $26 \%$ ) in HL-60 cells even though cell viability as measured by a dye-exclusion assay was high ( $\geqslant 98 \%$ ).

It is possible that PKC inhibition in ES cells may directly stimulate apoptosis; it is also possible that the increased apoptosis may be triggered by inhibition of cell proliferation resulting from PKC inhibition. There is considerable controversy over the role of PKC in apoptosis; both the inhibition and activation of PKC isoforms have been correlated with induction of apoptosis (Han et al., 2000). One hypothesis is that reduced PKC activity leads to apoptosis and that the increased incidence of apoptosis seen after PKC activation is due to a resulting downregulation of PKC (Leszczynski, 1996). However, there are at least twelve different PKC isozymes and there is evidence that some are anti-apoptotic and some pro-apoptotic (reviewed by Dempsey et al., 2000). There is also evidence that in some tissues there are distinct PKC isozymes for cell proliferation and apoptosis (Weller et al., 1999). There are differences in the expression and distribution of the various PKC isozymes throughout mammalian tissues and certain isoforms are localized to specific tissues (Nishizuka, 1992; Hofmann, 1997; Kanashiro and Khalil, 1998). These differences in PKC isozyme distribution and activity may explain the results of Ward et al. (2000), who found that the PKC inhibitor, staurosporine but not Bis I (an analogue of Bis II), induced apoptosis in mouse embryos over $24 \mathrm{~h}$.

The specificity of protein kinase inhibitors in general, including some bisindolylmaleimides, has been questioned. Davies et al. (2000) found that some bisindolylmaleimides inhibit protein kinases other than PKC (Bis II was not examined); in contrast, Han et al. (2000) found that the bisindolylmaleimides appear to be specific for PKC.

Cross-talk between signal transduction systems and between components of signalling systems is common (Houslay, 1991; Bourne, 1995; Zamponi et al., 1997). The present study used Bis II to inhibit PKC and TPA to activate PKC to examine the possible feedback regulation PKC may exert on PLC activity (Pfeilschifter et al., 1989; Boarder and Challiss, 1992). Inhibition of PKC by preincubation with Bis II caused a dosedependent increase in inositol phosphate formation. The opposite situation, activation of PKC with TPA, caused a decrease in inositol phosphate formation. These studies demonstrate that increased PKC activity downregulates PLC activity in ES cells. It has been known for some time that PKC phosphorylates the cytoplasmic domain of cell membrane receptors leading to their downregulation. PKC has also been shown to phosphorylate G-proteins and thereby inactivate them (Orellana et al., 1987; Smith et al., 1987). Whatever the site of action, PKC activity modulates the production of inositol phosphates in ES cells.

In summary, the work presented here indicates that the Ptdlns signalling system is essential for normal proliferation of ES cells and may also be involved in control of apoptosis. A limitation of the approach used in this study is its reliance on the use of pharmacological inhibitors and activators with their associated problems of specificity. However, the general conclusion that the Ptdlns system plays an important role in ES cells is strengthened by the fact that the evidence is based on the use of a number of inhibitors and activators.

The Ptdlns system in ES cells appears to be constitutively active possibly through the action of some autocrine or paracrine factor. Although the system appears to be essential for ES-cell proliferation, activation of the system is probably insufficient to stimulate normal ES-cell proliferation. Both ionomycin treatment to increase intracellular calcium and DOG or TPA treatment to activate PKC stimulated ES-cell proliferation but not to the same extent as FCS treatment. Burdon et al. (2002) described how cell proliferation, self renewal and differentiation in ES cells are controlled by at least three signalling systems: the JAK-STAT, the 
phosphatidylinositol-3-OH kinase, and the extracellularsignal-related kinase (ERK) systems. The Ptdlns signalling system and PLC can activate the ERK system, which is a complex and diverse system (van Biesen et al., 1996; Dhanasekaran et al., 1998). Although the present study indicates that Ptdlns system activity is essential for EScell proliferation, it is but one of a number of systems involved in ES-cell control.

As ES cells are derived from the inner cell mass of the blastocyst and therefore may be a useful model for inner cell mass development, these studies support the results of other studies (Kane et al., 1986; Kane, 1988; Stachecki and Armant, 1996a,b), indicating that the Ptdlns signalling pathway could play an important part in the regulation of blastocyst growth and development.

This work was funded by research grants from the Irish Health Research Board to M.T. Kane and from the National University of Ireland, Galway. The authors thank E. Notarianni formerly of the Department of Genetics, Cambridge University, for a gift of the embryonic stem cells.

\section{References}

Berridge MJ (1992) Phosphoinositides and cell signaling Fidia Research Foundation Neuroscience Award Lectures 6 5-45

Berridge MJ, Downes CP and Hanley MR (1982) Lithium amplifies agonistdependent phosphatidylinositol responses in brain and salivary glands Biochemical Journal 206 587-595

Berridge MJ, Dawson RMC, Downes CP, Heslop JP and Irvine RF (1983) Changes in the levels of inositol phosphates after agonist-dependent hydrolysis of membrane phosphoinositides Biochemical Journal 212 473-482

Berry N and Nishizuka Y (1990) Protein kinase C and T cell activation European Journal of Biochemistry 189 205-214

Billingsley ML, Polli JW, Pennypacker KR and Kincaid RL (1990) Identification of calmodulin-binding proteins Methods in Enzymology 184 451-467

Bleasdale JE, Thakur NR, Gremban RS, Bundy GL, Fitzpatrick FA, Smith RJ and Bunting S (1990) Selective inhibition of receptorcoupled phospholipase C-dependent processes in human platelets and polymorphonuclear neutrophils Journal of Pharmacology and Experimental Therapeutics 255 756-768

Boarder MR and Challiss JRA (1992) Role of protein kinase C in the regulation of histamine and bradykinin stimulated inositol polyphosphate turnover in adrenal chromaffin cells British Journal of Pharmacology $\mathbf{1 0 7}$ 1140-1145

Bourne HR (1995) Signal transduction - team blue sees red Nature $\mathbf{3 7 6}$ $727-729$

Burdon T, Smith A and Savatier P (2002) Signalling, cell cycle and pluripotency in embryonic stem cells Trends in Cell Biology 12432 438

Davies SP, Reddy H, Caivano M and Cohen C (2000) Specificity and mechanism of some commonly used protein kinase inhibitors Biochemical Journal $\mathbf{3 5 1}$ 95-105

Dempsey EC, Newton AC, Mochly-Rosen D, Fields AP, Reyland ME, Insel PA and Messing RO (2000) Protein kinase $C$ isozymes and the regulation of diverse cell responses American Journal of Physiology - Lung Cellular and Molecular Physiology 279 L429-L438

Denizot F and Laing R (1986) Rapid colorimetric assay for cell growth and survival: modifications to the tetrazolium dye procedure giving improved sensitivity and reliability Journal of Immunological Methods 89 271-277

Dhanasekaran N, Tsim S-T, Dermott JM and Onesime D (1998) Regulation of cell proliferation by G proteins Oncogene 17 1383-1394
Duffy C and Kane MT (1996) Investigation of the role of inositol and the phosphatidylinositol signal transduction system in mouse embryonic stem cells Journal of Reproduction and Fertility 108 87-93

Duffy C, Hynes A and Quinlan LR (1998) Methods for studying phosphoinositide metabolism in cultured cells. In Animal Cell Culture Techniques pp 149-169 Ed. M Clynes. Springer-Verlag, Berlin

Fahy MM and Kane MT (1992) Inositol stimulates DNA and protein synthesis, and expansion by rabbit blastocysts in vitro. Human Reproduction 7 550-552

Fahy MM and Kane MT (1993) Incorporation of $\left[{ }^{3} \mathrm{H}\right]$ inositol into phosphoinositides and inositol phosphates by rabbit blastocysts Molecular Reproduction and Development 34 391-395

Gallicano GI, Yousef MC and Capco DG (1997a) PKC - a pivotal regulator of early development Bioessays 19 29-36

Gallicano GI, McGaughey RW and Capco DG (1997b) Activation of protein kinase $\mathrm{C}$ after fertilization is required for remodeling the mouse egg into the zygote Molecular Reproduction and Development 46 587-501

Han Z, Pantazis P, Lange TS, Wyche JH and Hendrickson EA (2000) The staurosporine analog, Ro-31-8220, induces apoptosis independently of its ability to inhibit protein kinase C Cell Death and Differentiation 7 521-530

Hanson DA and Ziegler SF (2001) Regulation of ionomycin-mediated granule release from rat basophil leukemia cells Molecular Immunology 38 1329-1335

Higgins BD and Kane MT (2003) Inositol transport in mouse oocyte and preimplantation embryos: effects of mouse strain, embryo stage, sodium and the hexose transport inhibitor, phloridzin Reproduction 125111 118

Hofmann J (1997) The potential for isoenzyme-selective modulation of protein kinase C FASEB Journal 11 649-669

Houslay MD (1991) "Crosstalk": a pivotal role for protein kinase C in modulating relationships between signal transduction pathways European Journal of Biochemistry 195 9-27

Hynes AC, Sreenan JM and Kane MT (2000) Uptake and incorporation of myo-inositol by bovine preimplantation embryos from two-cell to early blastocyst stages Molecular Reproduction and Development 55265 269

Kanashiro CA and Khalil RA (1998) Signal transduction by protein kinase $\mathrm{C}$ in mammalian cells Clinical and Experimental Pharmacology and Physiology 25 974-985

Kane MT (1988) The effects of water soluble vitamins on the expansion of rabbit blastocysts Journal of Experimental Zoology 245 220-223

Kane MT (1989) Effects of the putative phospholipid precursors, inositol, choline, serine and ethanolamine, on formation and expansion of rabbit blastocysts in vitro. Journal of Reproduction and Fertility 87275 279

Kane MT and Bavister BD (1988) Vitamin requirements for development of eight-cell hamster embryos to hatching blastocysts in vitro. Biology of Reproduction 39 1137-1143

Kane MT, Carney EW and Bavister BD (1986) Vitamins and amino acids stimulate hamster blastocysts to hatch in vitro. Journal of Experimental Zoology 239 429-432

Kane MT, Norris M and Harrison RAP (1992) Uptake and incorporation of inositol by preimplantation mouse embryos Journal of Reproduction and Fertility 96 617-625

Kishimoto A, Mikawa K, Hashimoto K, Yasuda I, Tanaka S, Tominaga M, Kuroda T and Nishizuka Y (1989) Limited proteolysis of protein kinase C subspecies by calcium-dependent neutral protease (calpain) Journal of Biological Chemistry 264 4088-4092

Kraft AS and Anderson WB (1983) Phorbol esters increase the amount of $\mathrm{Ca}^{2+}$, phospholipid-dependent protein kinase associated with plasma membrane Nature 301 621-623

Leszczynski D (1996) The role of protein kinase C in regulation of apoptosis: a brief overview of the controversy Cancer Journal 9 308-313

Livneh E and Fishman DD (1997) Linking protein kinase C to cell-cycle control European Journal of Biochemistry 248 1-9

Mosmann T (1983) Rapid colorimetric assay for cellular growth and survival: application to proliferation and cytotoxicity assays Journal of Immunological Methods 65 55-63 
Nishizuka Y (1992) Intracellular signaling by hydrolysis of phospholipids and activation of protein kinase C Science 258 607-614

Orellana S, Solski PA and Brown JH (1987) Guanosine 5'-O(thiotriphosphate)-dependent inositol trisphosphate formation in membranes is inhibited by phorbol ester and protein kinase C Journal of Biological Chemistry 262 1638-1643

Pechhold K and Kabelitz D (1998) Measurement of cellular proliferation. In Methods in Microbiology Vol. 25 pp 59-78 Eds SHE Kaufmann and D Kabelitz. Academic Press, San Diego

Pfeilschifter J, Ochsner M, Whitebread S and De Gasparo M (1989) Down-regulation of protein kinase $\mathrm{C}$ potentiates angiotensin IIstimulated polyphosphoinositide hydrolysis in vascular smooth-muscle cells Biochemical Journal 262 285-291

Powis G and Phil D (1994) Inhibitors of phosphatidylinositol signalling as antiproliferative agents Cancer and Metastasis Reviews 13 91-103

Quest AFG (1996) Regulation of protein kinase C: a tale of lipids and proteins Enzyme and Protein 49 231-261

Robertson EJ (1987) Teratocarcinomas and Embryonic Stem Cells: a practical approach IRL Press, Oxford

Savickiene J, Gineitis A and Stigbrand T (1999) Modulation of apoptosis of proliferating and differentiating HL-60 cells by protein kinase inhibitors: suppression of PKC or PKA differently affects cell differentiation and apoptosis Cell Death and Differentiation 6 698-709

Smith CD, Uhing RJ and Snyderman R (1987) Nucleotide regulatory proteinmediated activation of phospholipase $\mathrm{C}$ in human polymorphonuclear leukocytes is disrupted by phorbol esters Journal of Biological Chemistry 262 6121-6127

Stachecki JJ and Armant DR (1996a) Regulation of blastocoele formation by intracellular calcium release is mediated through a phospholipase C-dependent pathway in mice Biology of Reproduction 55 1292-1298

Stachecki JJ and Armant DR (1996b) Transient release of calcium from inositol 1,4,5-trisphosphate-specific stores regulates mouse preimplantation development Development 122 2485-2496
Takai Y, Kishimoto A, Iwasa Y, Kawahara Y, Mori T and Nishizuka Y (1979) Calcium-dependent activation of a multifunctional protein kinase by membrane phospholipids Journal of Biological Chemistry $2543692-$ 3695

van Biesen T, Luttrell LM, Hawes BE and Lefkowitz RJ (1996) Mitogenic signaling via G protein-coupled receptors Endocrine Reviews 17 698714

Wang X-D, Kiang JG and Smallridge RC (1994) A phospholipase C inhibitor, U-73122, blocks TSH-induced inositol trisphosphate production, $\mathrm{Ca}^{2+}$ increase and arachidonic acid release in FRTL-5 thyroid cells Biochimica et Biophysica Acta 1223 101-106

Wang S, Gebre-Medhin S, Betsholtz C et al. (1998) Targeted disruption of the mouse phospholipase $C \beta 3$ gene results in early embryonic lethality FEBS Letters 441 261-265

Ward KW, Rogers EH and Hunter ES (2000) Comparative pathogenesis of haloacetic acid and protein kinase inhibitor embryotoxicity in mouse whole embryo culture Toxicological Sciences 53 118-126

Weller SG, Klein IK, Penington RC and Karnes WE (1999) Distinct protein kinase $\mathrm{C}$ isozymes signal mitogenesis and apoptosis in human colon cancer cells Gastroenterology 117 848-857

Williams RL, Hilton DJ, Pease S, Willson TA, Stewart CL, Gearing DP, Wagner EF, Metcalf D, Nicola NA and Gough NM (1988) Myeloid leukaemia inhibitory factor maintains the developmental potential of embryonic stem cells Nature 336 684-687

Zamponi GW, Bourinet E, Nelson D, Nargeot J and Snutch TP (1997) Crosstalk between $\mathrm{G}$ proteins and protein kinase $\mathrm{C}$ mediated by the calcium channel $\alpha_{1}$ subunit Nature 385 442-446

Received 23 December 2002.

First decision 11 February 2003

Revised manuscript received 25 February 2003.

Accepted 5 March 2003. 